\title{
A Review of Phosphate Mineral Nucleation in Biology and Geobiology
}

\author{
Sidney Omelon $\cdot$ Marianne Ariganello • \\ Ermanno Bonucci • Marc Grynpas • \\ Antonio Nanci
}

Received: 20 February 2013/ Accepted: 6 August 2013/Published online: 28 September 2013

(C) The Author(s) 2013. This article is published with open access at Springerlink.com

\begin{abstract}
Relationships between geological phosphorite deposition and biological apatite nucleation have often been overlooked. However, similarities in biological apatite and phosphorite mineralogy suggest that their chemical formation mechanisms may be similar. This review serves to draw parallels between two newly described phosphorite mineralization processes, and proposes a similar novel mechanism for biologically controlled apatite mineral nucleation. This mechanism integrates polyphosphate biochemistry with crystal nucleation theory. Recently, the roles of polyphosphates in the nucleation of marine phosphorites were discovered. Marine bacteria and diatoms have been shown to store and concentrate inorganic phosphate $(\mathrm{Pi})$ as amorphous, polyphosphate granules. Subsequent release of these $\mathrm{P}$ reserves into the local marine environment as $\mathrm{Pi}$ results in biologically induced phosphorite nucleation. Pi storage and release through an intracellular polyphosphate intermediate may also occur in mineralizing oral bacteria. Polyphosphates may be
\end{abstract}

The authors have stated that they have no conflict of interest.

\section{S. Omelon $(\square)$}

Chemical and Biological Engineering, University of Ottawa, Ottawa, Canada

e-mail: somelon@uottawa.ca

M. Ariganello · A. Nanci

Faculty of Dentistry, Université de Montréal, Montreal, Canada

E. Bonucci

Department of Experimental Medicine, La Sapienza University of Rome, Rome, Italy

M. Grynpas

Laboratory Medicine and Pathobiology, Samuel Lunenfeld

Research Institute of Mt. Sinai Hospital, Toronto, Canada associated with biologically controlled apatite nucleation within vertebrates and invertebrates. Historically, biological apatite nucleation has been attributed to either a biochemical increase in local Pi concentration or matrixmediated apatite nucleation control. This review proposes a mechanism that integrates both theories. Intracellular and extracellular amorphous granules, rich in both calcium and phosphorus, have been observed in apatite-biomineralizing vertebrates, protists, and atremate brachiopods. These granules may represent stores of calcium-polyphosphate. Not unlike phosphorite nucleation by bacteria and diatoms, polyphosphate depolymerization to Pi would be controlled by phosphatase activity. Enzymatic polyphosphate depolymerization would increase apatite saturation to the level required for mineral nucleation, while matrix proteins would simultaneously control the progression of new biological apatite formation.

Keywords Biomineralization: mechanisms - Bone and cartilage development - Crystal structure/ crystallinity

\section{Introduction}

In nature, different calcium phosphate minerals are produced within a wide range of environments by geological (igneous apatite), geochemical and/or geomicrobiological (phosphorite), and biological (biological apatite) processes. Igneous apatite minerals nucleate and crystallize from molten, phosphate-rich rock, forming crystalline fluorapatite $\left(\mathrm{Ca}_{5} \mathrm{~F}_{2}\left[\mathrm{PO}_{4}\right]_{3}\right)$, chlorapatite $\left(\mathrm{Ca}_{5} \mathrm{Cl}_{2}\left[\mathrm{PO}_{4}\right]_{3}\right)$, or hydroxyapatite $\left(\mathrm{Ca}_{5}[\mathrm{OH}]_{2}\left[\mathrm{PO}_{4}\right]_{3}\right)$ [1]. In less extreme environmental conditions, biochemical pathways are attributed to the precipitation of biological apatite and phosphorite (minerals that 
contain $>6 \% \mathrm{P}$ on a dry basis [2]) within aqueous environments at neutral to basic $\mathrm{pH}$.

Phosphate concentrations in environmental (e.g., marine), intracellular, or extracellular (e.g., osteoid) aqueous and calcium-containing environments are too low for spontaneous, inorganic formation of a first calcium phosphate mineral from solution (nucleation). However, calcium phosphate minerals do nucleate and grow in these environments. The chemical mechanism of phosphorite mineral nucleation in the environment has been a question for over 100 years, as has the chemical mechanism of biological apatite nucleation within organisms.

The process of apatite biomineralization was proposed to be conserved over many eras and over a wide range of life forms. Thompson [3] quoted J. H. Mummery, who in 1914 wrote "Calcification in both dentine and enamel is in great part a physical phenomenon; the actual deposit in both occurs in the form of calcospherites, and the process in mammalian tissue is identical in every point with the same processes occurring in lower organisms." This potentially evolutionarily conserved mechanism has allowed for the formation of elegant structural and metabolically active apatitic skeletons for a wide range of vertebrates and some invertebrates that was poetically described by Quekett:

The laws of Nature are undeviating in the construction of the skeleton of vertebrate animals: the same regularity in structure, the same method of arrangement of the bone-cells, has existed from the time when the surface of our planet was first inhabited by a vertebrate animal up to the present period. The largest bones of the mighty Iguanodon (say of 100 feet in length), of the Ichthyosaurus - the tyrant of the water in former ages, of the gigantic Tortoise of the Himalaya range (some 20 feet in length), present no appreciable difference, in their minute structure, from the pigmy race of lizards that we now tread under our feet. The bones of the Mastodon and the huge Megatherium, the giants of the land, are no more remarkable for the coarseness of their structure than are those of the smallest of the mammiferous quadrupeds, the mouse, and such has been the prevailing law from the commencement of the earth's existence, and such, no doubt, will continue to the end of time [4].

This review summarizes recent advances in understanding the chemical mechanisms of phosphorite biomineralization induced by organisms much smaller than mice. Sulfide-oxidizing marine bacteria and diatoms have been discovered to share a common mechanism of inorganic phosphate $(\mathrm{Pi})$ concentration and storage. The geobiology community has reported that low environmental Pi concentrations can be concentrated and stored by biochemical polymerization of $\mathrm{Pi}$ into polyphosphate $\left(\left[\mathrm{PO}_{3}{ }^{-}\right]_{\mathrm{n}}\right.$, polyP) molecules [5]. Pi release from polyP can occur through controlled phosphatase hydrolysis, or through uncontrolled hydrolysis in the environment. Either of these pathways results in an increase in local Pi concentration, which increases phosphate mineral saturation. This increase in phosphate mineral saturation may allow for spontaneous phosphate mineral nucleation in the environment, or within organisms.

This article will provide a brief summary of polyP chemistry, phosphorite and apatite mineralogy, as well as the chemistry of mineral nucleation. This will provide a background for reviewing two phosphorite mineral nucleation pathways, and a commentary on the similarities of phosphate mineral nucleation reported in the fields of geobiology, dentistry, and biology.

\section{PolyP is Both a Mineralization Inhibitor and a Bioavailable Pi Source}

In the skeletal mineralization research community, polyPs are noted to be "highly inhibitory to calcium phosphate nucleation and precipitation" [6]. Francis [7] demonstrated that polyPs inhibit crystalline calcium hydroxyapatite nucleation and growth from solution as long as they are intact. Temperature, $\mathrm{pH}$, and some enzymes enhanced their hydrolytic instability, decreasing the polyP concentration and therefore reducing their inhibitory activity.

Fleisch et al. [8] studied the mineralization inhibitor effect of pyrophosphates $\left(\mathrm{P}_{2} \mathrm{O}_{7}{ }^{4-}\right)$ and polyPs on the mineralization of chick embryo femurs grown in culture. Normalized to 4 and $16 \mu \mathrm{g}$ phosphorus $(\mathrm{P}) / \mathrm{mL}$, polyP inhibited mineralization. However, $1 \mu \mathrm{g} \mathrm{P} / \mathrm{mL}$ "seemed to activate calcification," which was not observed in their previous in vitro studies [6]. They attributed this to the possibility that phosphatase enzymes may have cleaved the phosphate esters, destroyed the inhibitory molecules, and that this "might lead to facilitation of calcium phosphate deposition" [8]. Fleisch and Neuman [6] noted that "ossifiable cartilage and bone contain enzymes which destroy polyphosphates" and suggested that the colocation of polyPs and phosphatase enzymes may remove mineral inhibition and "activate calcification." What they did not discuss, and has recently been accepted in the geobiology literature, is that destruction of polyP produces Pi. While complete polyP destruction removes the inhibitor, at the same time it increases Pi concentration. In the presence of free calcium ions, this increases the chemical potential for nucleating calcium phosphate minerals. Much as glucose concentration can be controlled by glycogen formation and destruction, Pi concentration can be controlled by polyP 
formation and destruction. Interest in inorganic polyP biochemistry is growing [9] and has provided interesting possibilities for enzymatic control of free Pi concentration.

PolyPs (metaphosphates) were identified within yeast in 1936 [10]. In the 1940s, yeast was observed to concentrate $\mathrm{P}$ as polyP within volutin granules after periods of $\mathrm{Pi}$ starvation [11-13]. The presence of polyPs was further confirmed within yeast cells in 1975 by ${ }^{31} \mathrm{P}$ NMR [14]. In 1980, the fluorescent dye 4',6-diamidino-2-phenylindole (DAPI), typically used to stain DNA, was used to identify intracellular polyP within volutin granules [15]. The amplified blue emission of the excited DAPI-DNA complex has a maximum intensity at $\sim 340 \mathrm{~nm}$, while the DAPI-polyP complex emission is yellow-green (maximum intensity at $\sim 526 \mathrm{~nm}$ ) [15]. PolyP identification methods have different deficiencies [16]. For example, histological stains of polyP are not specific, the DAPI-RNA complex fluoresces at $500 \mathrm{~nm}$ [17], and samples often require processing to concentrate polyP for detection with ${ }^{31} \mathrm{P}$ NMR. These sample preparation methods can remove or break down polyP.

PolyPs are negatively charged polyanions with great affinity for calcium and other multivalent cations [18]. PolyP chelation of calcium reduces the free calcium concentration [19] and produces a neutral, amorphous, $\left[\mathrm{Ca}\left(\mathrm{PO}_{3}\right)_{2}\right]_{\mathrm{n}}$ complex. This complex is a bioavailable reserve of $\mathrm{Ca}^{2+}$ and $\mathrm{Pi}$. The formation of these complexes has been attributed to mitochondria; their production and metabolism in mammalian cells have been investigated [20]. The effect of polyP on yeast and animal cell mitochondrial functions and dysfunctions [21] and polyP roles in biochemistry [9] have been recently reviewed [22].

\section{PolyP is a Bioavailable Pi and Calcium Storage Strategy}

Using electron microscopy, electron-dense granules were observed in rat liver mitochondria from a calcium and $\mathrm{Pi}$ accumulation study in 1964 [23]. These mitochondrial, electron-dense granules contained high calcium and $\mathrm{Pi}$ concentrations (reported to be "at least $0.5 \mathrm{M}$ " when Pi was measured by the Fiske-Subbarow method [24] and $0.8 \mathrm{M}$ by Lehninger in 1970 [25]). However, these granules were surprisingly amorphous [23]. At these high Pi concentrations, a calcium phosphate mineral was expected to nucleate. However, if the $\mathrm{P}$ was assumed to be from polyP, which offers a higher P density than Pi [26], then the structure of the calcium- and P-rich granule would be expected to be amorphous. Amorphous calcium-polyP requires very high temperatures to crystallize [27].

Discrete granules containing calcium-polyP complexes have been proposed to be conserved from bacteria to humans [28]. Theoretically, the Ca:P ratio of this complex is less than 1 ; the exact value is a function of the polyP chain length. The neutral $\mathrm{Ca}$-polyP complex represents a concentrated, bioavailable calcium and $\mathrm{P}$ store as polyP destruction produces $\mathrm{Pi}$ and frees $\mathrm{Ca}^{2+}$. At neutral to basic $\mathrm{pH}$, this polyP depolymerization simultaneously removes an apatite mineralization inhibitor and increases apatite saturation-the chemical potential for apatite nucleation from solution.

Although polyP depolymerization is thermodynamically favored in aqueous environments, the kinetics are slow at neutral $\mathrm{pH}$ [29], but accelerated by phosphatase enzymes such as alkaline phosphatase (APase) [30]. PolyP is a substrate for both tissue-nonspecific APase [31] and intestinal APase [32]. APases cleave Pi from ester phosphates at neutral to basic $\mathrm{pH}$ [33] and are theorized to cleave Pi from polyP in diatoms [34].

The relationship between $\mathrm{Ca}$ and $\mathrm{P}$ concentration and storage as $\mathrm{Ca}$-polyP granules, and the geobiological production of phosphorite mineral from these concentrated stores in bacteria and diatoms will be described. This will be compared with a review of $\mathrm{Ca}$ - and $\mathrm{P}$-containing granules and APases identified in protists, brachiopods, and vertebrates that control biological apatite mineralization.

\section{Apatite, Phosphorite, and Biological Apatite Minerals}

The chemical and physical characteristics of minerals lay the foundation for explaining the processes that form them. The family of apatite minerals is defined with the generalized formula $\mathrm{A}_{5}\left(\mathrm{XO}_{4}\right)_{3} \mathrm{Z}$, where $\mathrm{A}$ is a divalent cation that is most often $\mathrm{Ca}, \mathrm{X}$ is most commonly $\mathrm{P}$, and $\mathrm{Z}$ represents an anion, which can be one or more of $\mathrm{F}, \mathrm{Cl}$, and $\mathrm{OH}$ [1]. Apatite minerals are very tolerant of elemental and molecular (e.g., $\mathrm{HPO}_{4}{ }^{2-}, \mathrm{CO}_{3}{ }^{2-}$ ) substitutions, so the apatite group is large, with over 25 members [35]. This chemical diversity means that exact analysis of apatite mineral samples is challenging.

Geological phosphorite is "composed essentially of carbonate apatites which are usually moderately high in fluorine" [36]. Although their chemical definition is similar to bone mineral, phosphorites vary in chemical composition, containing apatite and carbonated fluorapatite [37-39] and vary in mineralogy [40]. Phosphorite rock generally describes a group of sedimentary (deposited by water, ice, or wind) rock deposits with high $\mathrm{P}$ concentration [41]. Phosphorites have been described as "sedimentary deposits with high phosphorus concentration" [18] and minerals with a lower limit of $>9 \% \mathrm{PO}_{4}{ }^{3-}$ [42] because these deposits contain phosphate rocks of different mineralogies [40]. Many phosphorite formation theories have been proposed, including inorganic precipitation and biomineralization processes [43]. 
Biological apatite minerals are formed within vertebrate skeletal tissues, within inarticulate brachiopods (order Atremata, superfamily Lingulacea, and order Neotremata) [44-46] and the protozoa Spirostomum ambiguum [47]. The vertebrate skeletal mineral was identified as containing calcium, phosphate, and carbonate in 1894 [48] and further described as a poorly crystalline carbonated apatite mineral in 1927 [49]. In 1929, the fluoride component of bone mineral was identified [50]. Since then, mineralogists have described bone mineral as a substituted carbonated apatite similar to dahllite (an apatite mineral with a fluoride content $<1 \%$ ) [51, 52]. A proposed structural formula for bone mineral is $(\mathrm{Ca}, \mathrm{X})_{10}\left(\mathrm{PO}_{4}, \mathrm{CO}_{3}, \mathrm{Y}\right)_{6}(\mathrm{OH}, \mathrm{Z})_{2}$ with $\mathrm{X}$ substituting cations and $\mathrm{Y}, \mathrm{Z}$ substituting anions (with the stoichiometry changing accordingly) ([53] citing [54-57]). Bone apatite is consistently nanometer-scaled [58]; is less crystalline than highly crystalline, synthetic hydroxyapatite [59]; contains carbonate and fluoride [50]; is highly substituted [36]; and contains a small fraction of the hydroxyl groups expected in pure hydroxyapatite [60, 61]. Since Neuman and Neuman [62] stated that "the hydroxy apatite is the only solid phase of the $\mathrm{Ca}-\mathrm{PO}_{4}-\mathrm{H}_{2} \mathrm{O}$ system which is stable at neutral $\mathrm{pH}$," the literature has mistakenly described the mineral in bone as "hydroxyapatite". Unlike phosphorite, the consistent size and chemistry of skeletal mineral suggest that its nucleation is a highly controlled process.

Bone mineral growth is predicted from the calcium and phosphate concentrations in serum, but these concentrations do not explain bone mineral nucleation. How biological apatite first nucleates within the extracellular matrix (ECM) is still an open question, and must involve the active participation of matrix proteins. As described by McConnell [36], "increments in the organic and inorganic chemistries can be isolated for separate consideration, and factors which interrelate these systems are being sought." Ultimately controlled by biochemical processes, biological apatite mineral nucleation should also follow the physical chemistry principles which describe how minerals nucleate from solution.

\section{Mineral Saturation States and Nucleation}

A mineral nucleates from solution if the mineral saturation state is above the equilibrium (saturated) value. The equilibrium saturation value at a given temperature is also termed the "solubility product" and is reported as $K_{\text {sp }}$ for pure minerals. The mineral saturation state is proportional to the activities of its component ions, raised to the power of their stoichiometric coefficients (ion activity product [IAP] [63]). If the IAP is larger than the mineral $K_{\mathrm{sp}}$, the solution is "supersaturated" with respect to that mineral.
The degree of supersaturation dictates the possibility of crystal growth (lowest supersaturation), heterogeneous nucleation (intermediate supersaturation), or homogeneous nucleation (highest supersaturation) [64]. The IAP of different calcium phosphate minerals at different $\mathrm{pH}$ values was reported by Larsen [65].

Fleisch and Neuman [6] noted that "extracellular fluids are supersaturated with respect to bone mineral, and that the concentrations of calcium, $\mathrm{Pi}$, and hydroxyl ions are sufficiently high to support the growth of bone mineral crystals once the initial crystals have formed." After describing this low supersaturation state that explains observed bone crystal growth, they continue, "however, the concentrations of these ions are not high enough to precipitate spontaneously. Some seeding mechanism seems required to initiate crystallization" (referencing [62]). Spontaneous precipitation is termed "homogeneous nucleation" and requires the largest supersaturation values. Nucleation on another solid phase requires a lower supersaturation value. Collagen was proposed to be the solid phase for bone mineral nucleation, resulting in a lower apatite supersaturation value required for heterogeneous nucleation of the ECM [66].

This theory of heterogeneous nucleation of apatite on collagen was termed the "eptitactic" theory [67]. However, the physiological concentrations of calcium and Pi [68] are not high enough to induce heterogeneous precipitation on collagen [6] or from solution [69]. In 1923, Robison [70] suggested that an enzymatically controlled Pi-concentration increase would be possible by cleaving "an organic ester of phosphoric acid." One candidate enzyme for this activity in bone tissue is APase, which is associated with apatite biomineralization [71]. Geochemists and geomicrobiologists have similarly attributed inorganic and biological phosphorite precipitation to a discrete, local increase in Pi concentration.

\section{Phosphorite Nucleation}

Kazakov [72] reviewed the theories for geological phosphorite formation processes in 1937. He surveyed the range of theorized mechanisms, including inorganic precipitation, biological ("biolitic") formation by plankton, residual skeletons ("necton") that settle on the ocean floor, and organisms that live at the bottom of the ocean ("bentos"), referencing papers from the late 1800s and early 1900s. There are some examples of inorganic processes, such as mixing waters of different compositions in the environment, which will increase phosphorite saturation. The simplest inorganic phosphorite precipitation process is mixing calcium-rich waters (e.g., seawater or limestone deposit pore waters) with phosphate-rich waters (e.g., deep 
sea upwelling or rainwater that has percolated through guano deposits). If the resulting mixed solution is supersaturated with respect to phosphate mineral at neutral or basic $\mathrm{pH}$, then the chemical potential exists for homogenous and/or heterogenous calcium phosphate mineral nucleation.

Another P source from geological aqueous environments comes from sudden and local $\mathrm{P}$ fluxes from sediments which are coincident with anaerobic conditions. In 1912, it was proposed that under "conditions probably anaerobic but not yet well understood ... phosphoric acid also liberated will react with various substances, particularly lime salts. With the latter, it produces the mineral collophanite, a hydrous calcium carbo-phosphate" ([73] citing [74]). Since the 1930s, this inorganic process of Pi release was related to the reduction of $\mathrm{Fe}$ (III) to $\mathrm{Fe}$ (II). This chemical reduction of iron dissolves $\mathrm{Fe}(\mathrm{II})$ and releases the $\mathrm{Pi}$ that was adsorbed to $\mathrm{Fe}$ (III) hydroxide solids that dissolve in the anoxic sediment ([75] citing [76], [77]). It was later proven that organisms can concentrate and store Pi from their environment [78] and then release Pi to survive periodic anaerobic environments [79] or after death $[75,80]$. This biologically driven Pi release can increase phosphorite saturation in the vicinity of the Pireleasing organisms. This is an example of biologically induced mineralization [81] as the mineralization occurs in the environment around the organism as an indirect consequence of biological activity. Because the conditions of this environment may change, the biologically induced phosphate minerals may not be consistent in size, composition, or mineralogy, which is characteristic of phosphorite minerals.

\section{Biologically Induced Apatite Nucleation: Benthic Bacteria}

The "biologic" theory, proposing that life-forms play a role in phosphorite formation, was published in 1936 [82]; but the exact biochemical mechanisms were unknown at that time. More recently, Pi-accumulating marine bacteria Pseudomonas and Acinetobacter were thought to be involved in modern (meaning still actively forming) phosphorite formations [83]. This was proposed because similar bacterial species accumulate $\mathrm{Pi}$ as polyP in biological activated sludge systems used to treat wastewater ([83] citing [84]). These bacteria concentrate $\mathrm{Pi}$ as polyP in oxic conditions; when their environment becomes anoxic, they depolymerize polyP as an energy source, releasing Pi. This switch in energy production was proposed to explain the local $\mathrm{Pi}$ concentration increase in the calcium-rich marine pore water, leading to apatite precipitation. Marine bacteria above modern phosphorite deposits were collected, and intracellular polyPs were identified with chemical fractionation methods [83].

Modern phosphorite formation has also been associated with two species of sulfide-oxidizing bacteria that inhabit microbial mats within the marine sediment: Beggiatoa [85, 86] and Thiomargarita namibiensis [79, 87]. In situ $\mathrm{Pi}$ concentrations of up to $300 \mu \mathrm{M}$ were measured within ocean sediment composed of $\sim 25 \%$ hydroxyapatite and populated by Thiomargarita [79]. This represents a remarkable increase in $\mathrm{Pi}$ concentration as open-ocean $\mathrm{Pi}$ concentrations are generally less than $1 \mu \mathrm{M}$ [88]. Incubation of these bacteria in the laboratory demonstrated Pi release under anoxic conditions [79]. It was concluded that polyP hydrolysis caused the increase in marine sediment pore water $\mathrm{Pi}$ concentration, leading to biologically induced hydroxyapatite precipitation [79].

Goldhammer et al. [86] used ${ }^{33} \mathrm{P}$ to trace the path of $\mathrm{Pi}$ from an in vitro aqueous medium into organic-rich sediments obtained from a modern phosphorite location that included Thiomargaria and Beggiatoa. They noted that under anoxic and oxic conditions these sulfide-oxidizing bacteria accumulated ${ }^{33} \mathrm{P}$, with more accumulation in oxic conditions and no detectable ${ }^{33} \mathrm{P}$ incorporation into the dead (control) cells. Authigenic (locally formed) apatite containing ${ }^{33} \mathrm{P}$ formed most rapidly under anoxic conditions, while no apatite was formed in the control experiments with dead cells. The authors concluded that authigenic apatite formation required the presence of living cells such as Thiomargarita and Beggiatoa, and that these cells accumulated phosphate as polyP and released $\mathrm{Pi}$ under anoxic conditions [86]. Brock and Schulz-Vogt [89] cultured Beggiatoa and concluded that Pi release from intracellular polyP stores was associated with anoxia and increasing sulfide concentrations (Fig. 1).

This mechanism of biological concentration of $\mathrm{Pi}$ as polyP and release to nucleate phosphorite gave rise to the recent comment in a microbiology review that "It seems that we are in the midst of a revolution in our understanding of the origins of phosphatic mineral deposits" [5]. The review describes the "compelling mechanism" for concentrating $\mathrm{P}$ as polyP within marine sulfide-oxidizing bacteria that live at the bottom of the ocean, and how polyP is a source of $\mathrm{Pi}$ that is released into the marine sediment pore waters. Also noted were the many gaps that remain in the detailed understanding of how this biological Pi-release process results in apatite precipitation.

The role of bacteria in apatite mineralization may not be limited to geological environments. A 1967 editorial titled "Microbiologic Calcification: Bone Mineral and Bacteria" by Ennever and Creamer [90] interpreted and expanded on the work by Bulleid in 1925 [91]. Their conclusion was that he had observed apatite mineralization caused by the action of the dental bacteria Bacterionema matruchotii. 


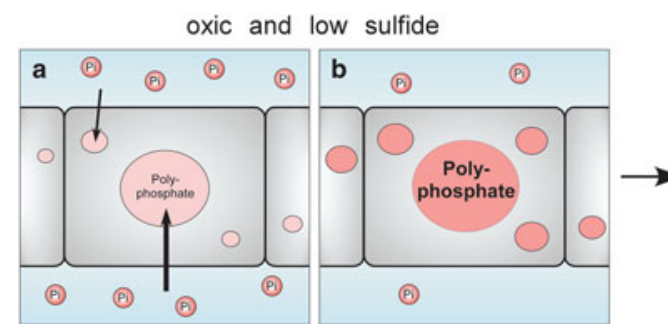

Fig. 1 Proposed phosphate uptake and release by Beggiatoa. a, b Under oxic conditions and exposure to low sulfide concentrations, phosphate is taken up by Beggiatoa and accumulated as polyphosphate. The phosphate concentration in the medium decreases. c, d When the conditions change to anoxia and exposure to sulfide

\section{Biologically Induced Apatite Nucleation: Oral Bacteria}

There are many types of oral bacteria within dental plaques; some of them are correlated with dental calculus formation. Dental calculus includes a range of calcium phosphate minerals, including apatite, Whitlockite, tricalcium phosphate, and octacalcium phosphate [92-95]. To test if the aqueous oral environment provided the chemical driving force (IAP) for calculus formation, Poff et al. [96] surveyed patients with a wide range of supragingival calculus severity and compared the calculus severity to the measured hydroxyapatite saturation in their saliva. The results showed no correlation, suggesting that inorganic calcium phosphate nucleation was not the mechanism of calculus formation. Poff et al. also discussed the possible role of mineral nucleation and growth inhibitors such as pyrophosphate [97] and polyphosphate [7], but concluded that they did not affect the study conclusions.

Bacteria are known to contribute to dental calculus, although their specific role is not clear. Microbes encased in mineral result in a porous calculus structure [98], suggest extracellular mineralization occurs. The varied mineral composition in dental calculus may reflect the varied environment in which induced biomineralization takes place [81]. The mechanism for these calcification events has not yet been explained.

Dental calculus formation and intracellular mineralization have been associated with the oral microbe Bacterionema matruchotii. Ennever et al. [99] reviewed their work on this organism [90], explaining that apatite was identified in the cell-ash in 20-day-old cells and identified intracellular apatite mineral within fixed and embedded cells [100]. A survey of oral bacteria concluded that many, including Bacterionema matruchotii, contained "dark-staining, electron-dense granules. . 15 to $500 \mathrm{~nm}$ in diameter, probably polyphosphate granules" [101]. Takazoe and Nakamura [102] identified "metachromatic granules and intracellular calcification of Bacterionema matruchotii" and reported that the granules were "chiefly polymetaphosphate." They used both measurement of the metachromasy of toluidine blue and chemical analysis of the extracted granules to confirm their polymetaphosphate conclusion. They observed the absorption maximum of toluidine blue shift when exposed to the extract, and the destruction of the metachromatic extract by an acidic treatment. They also measured an increased $\mathrm{Pi}$ concentration in the extract after acid hydrolysis. They noted that polyP is a mineralization inhibitor, and that it might have an inhibitory effect against dental calculus formation [102]. Dentifrices containing polyP have since proven to reduce oral bacteria adherence $[103,104]$ and to decrease dental caries formation [105].

The association of exogenous polyPs with mineral inhibition may have prevented Takazoe and Nakamura [102] from associating these intracellular granules within Bacterionema matruchotii as a Pi source for phosphate mineral formation. The identification of polyP within Bacterionema matruchotii, and the association of APase activity with bacteria of dental plaque [106, 107] provide two clues to a possible chemical mechanism for increasing calcium phosphate mineral supersaturation within oral microbial biofilms.

Could a parallel be drawn between induced phosphorite nucleation by bacterial $\mathrm{Pi}$ release into marine bacterial mats from intracellular polyP, and calculus nucleation by oral bacterial Pi release into biofilms from intracellular polyP stores? This mechanism could explain how calcium phosphate mineral supersaturation is increased within the oral biofilm, causing calcium phosphate mineral nucleation. This induced biomineralization process within the biofilm environment would also explain the varied dental caries mineralogy. Direct evidence of this proposed induced apatite biomineralization process by oral bacteria was not identified in the literature. The recent literature does provide a second biologically induced, phosphoriteformation mechanism in the deep ocean that involves polyP. 


\section{Apatite Nucleation from PolyP Granules: Diatoms}

In 1936, Cayeux [108] proposed that algae were responsible for the phosphorite deposits colocated with siliceous rock deposits. In the 1960s, algae were also noted for their ability to accumulate $\mathrm{Pi}$ from their environment. In the laboratory, Phaeodactylum tricornutum reduced $\mathrm{Pi}$ concentrations from its surroundings to less than $7.2 \times 10^{-10}$ $M$ [109]. In chlorococcalean algae, granules containing polyP stained with toluidine blue [110]. This staining method was similarly used to conclude the presence of polyP granules within the diatom Melosira varians [111]. The authors theorized that the polyP granules were a bioavailable $\mathrm{Pi}$ store, as it is one of the many proposed biological roles of polyP within unicellular organisms [112]. The validity of the toluidine blue staining method for polyP in algae was validated in 1996, when electron-dense bodies containing calcium and polyP were identified in Chlamydomonas eugametos with ${ }^{31} \mathrm{P}$ NMR and DAPI. This study also colocated $\mathrm{Ca}$ and $\mathrm{P}$, with $\mathrm{Ca}: \mathrm{P}$ ratios $<1$, by $\mathrm{X}$-ray microanalysis [113].

Phytoplankton are theorized to produce and secrete APase into their environment in order to release Pi from dissolved organic phosphorus, and increase the local Pi concentration [114]. In 2012, Dyhrman et al. [34] identified cell surface-associated APase, suggesting that Pi hydrolysis and Pi uptake may be "tightly coupled." They also identified polyP polymerase regulation, with cellular $\mathrm{P}$ condensing to polyP, and related their results to the relationship between diatoms and marine phosphorite mineral formation identified by Diaz et al. in 2008 [80].

PolyP granules were detected in marine sediment, where they were mixed with granules of similar size that have been identified as apatite by X-ray fluorescence (Fig. 2) [80]. These apatite granules were theorized to originate from diatoms, as Diaz et al. [80] observed that the 0.5-3 $\mu \mathrm{M}$ polyP granules were similar in size to diatom granules. PolyP stores within diatoms are normally protected from the environment within their silica skeleton (frustule). Diaz et al. [80] proposed that after diatom death, bacteria consume the outer organic layer that protects the silica within the frustule, resulting in silica dissolution. After falling through the water column, polyP granules freed from or exposed within compromised frustules would be exposed to the sediment environment.

Although the exact chemical mechanism of granular diatom polyP depolymerization in the sediment is not understood, it was assumed that this polyP is the source of increased local $\mathrm{Pi}$ concentration, inducing apatite precipitation in the calcium-rich seawater that infuses the sediment [80]. It was suggested that polyP "appears to nucleate authigenic apatite growth" and "without extensive interaction with the free sedimentary phosphate pool." This suggests that the $\mathrm{P}$ within the granule transformed into $\mathrm{Pi}$ that nucleated and formed an apatite mineral grain. The possibility that granules containing calcium and polyP could be transformed into apatite minerals echoes a theory from 1846 for bone mineralization [4]. This theory proposed that cells produce mineral precursor granules that are secreted into the ECM, where they transform into apatite granules.

\section{Mitochondrial Ca-/P-Rich Granules}

In 1968, mitochondria were proposed to have a role in apatite biomineralization: concentrating intracellular calcium and $\mathrm{Pi}$ [115]. Ca- and P-containing granules were identified within the mitochondria of osteoclasts [116], chondrocytes [117, 118], osteoblasts [119], osteocytes [120-122], calcifying cartilage [123], and mineralizing bone [124-126] if samples were prepared with anhydrous or cryo techniques. Initial calcification loci, described as "roundish bodies of cellular origin" identified by Bonucci [127], led him to suggest that ions may have accumulated within mitochondria. Bonucci et al. [128] examined the ultrastructure of experimentally calcified mitochondria from various cell types, and found needle-shaped and roundish, electron-dense deposits, both showing an intimate relationship with an organic substrate having the same morphology as the inorganic deposits. Examination of rat liver mitochondrial granules after tissue microincineration resulted in the suggestion that they could be apatite precursors [129]. Incineration of bone-cell mitochondria produced unidentified "mineral" [122], while extracted mitochondrial granules after heating at $600{ }^{\circ} \mathrm{C}$ produced hydroxyapatite, Whitlockite, or a mixture of both [130].

In 1970, Lehninger wrote "We have adopted the working hypothesis. . that what living cells "do" to $\mathrm{Ca}^{2+}$ and phosphate is to bring about their accumulation in the mitochondria to such concentrations as to exceed the solubility product of tricalcium phosphate, a process that cannot occur spontaneously in extracellular fluid, nor for that matter in the extramitochondrial cytoplasm. The end products of this stage are suggested to be "micro-packets" of insoluble amorphous tricalcium phosphate in the mitochondrial matrix, which we regard as the essential precursors of extracellular hydroxyapatite" [25]. This amorphous tricalcium phosphate theory has not been demonstrated. However, in 2012, electron-dense, noncrystalline, Ca- and P-rich granules were identified within, and possibly being transferred from, osteoblastic cell culture mitochondria processed with high-pressure freezing (HPF) and freeze substitution (FS) [131]. Similar nano-scale granules, with $\mathrm{Ca} / \mathrm{P}$ ratios less than the $1.5 \mathrm{Ca} / \mathrm{P}$ ratio of amorphous calcium phosphate (ACP) [132], were detected in different conditions. The $\mathrm{Ca} /$ $\mathrm{P}$ ratio of ultracryomicrotomed mitochondrial granules in two chick tibias measured with high spatial resolution, 
Fig. 2 X-ray fluorescence micrograph and fluorescence spectra of phosphorus-rich regions in Effingham inlet sediment. Sedimentary phosphorus (red) appears as distinct, heterogeneously distributed submicrometer-sized particles against a comparatively uniform background of sedimentary aluminum (blue) and magnesium (green). On the basis of high-resolution X-ray spectroscopic characterization, about half of the 147 phosphorus-rich regions examined in our samples were found to be polyphosphate, whereas the other half were classified as apatite, a common calcium phosphate mineral. From Diaz et al. [80]. Reprinted with permission from American Association for the Advancement of Science (AAAS) (Color figure online)
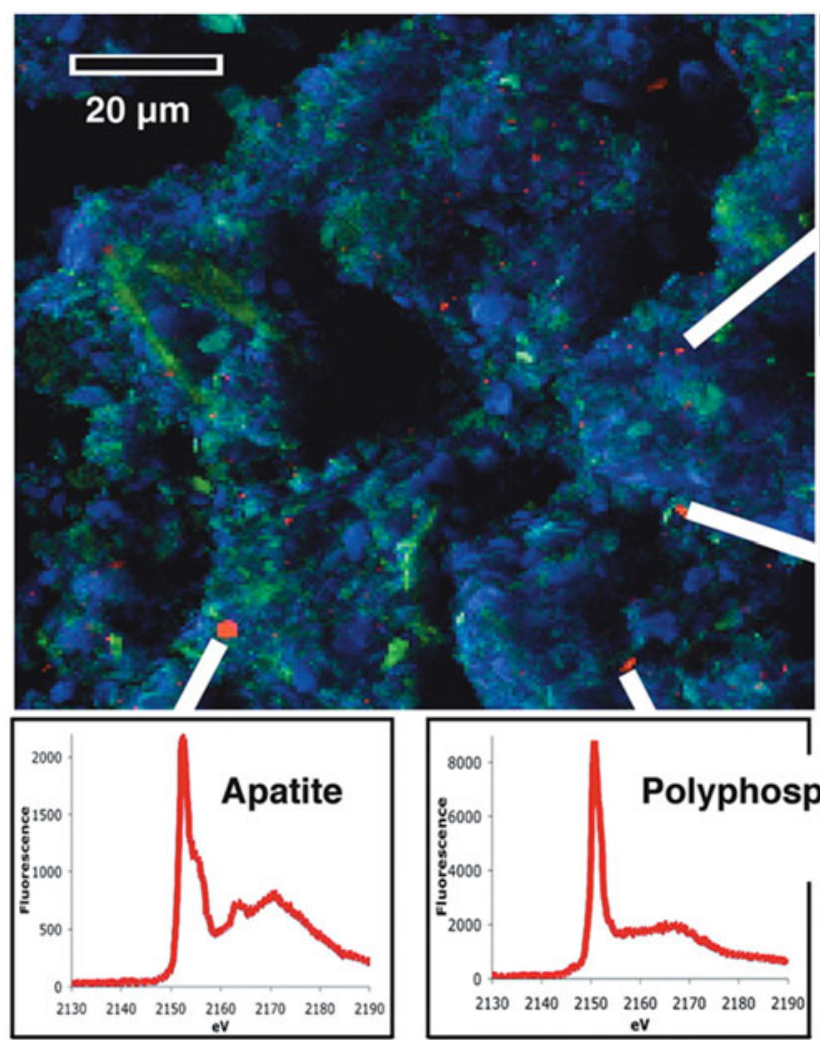

nondispersive electron probe $\mathrm{X}$-ray microanalysis were $1.04 \pm 0.07$ and $1.43 \pm 0.14$ [125]. $\mathrm{Ca} / \mathrm{P}$ ratios of granules within undecalcified calcifying cartilage prepared under anhydrous conditions measured 0.8-1.1 [123], and the same ratio measured in mineralizing murine bone granules in cryo conditions was $0.75 \pm 0.22$ [133]. The $\mathrm{Ca} / \mathrm{P}$ ratios of these granules are lower than those of tricalcium phosphate, hydroxyapatite, or ACP; but they are comparable with the $\mathrm{Ca} / \mathrm{P}$ ratio $<1$ measured for $\mathrm{Ca}$-polyP complexes by electron probe $\mathrm{X}$-ray microanalysis [125].

\section{Ca- and P-Rich Granules in Apatite Biomineralizing Organisms}

Intra- and extracellular apatitic granules, which have also been described by alternate names such as "spherules," "spherulites," "microspheres," and "calcospherites," were observed in calcifying cartilage [44-48, 118, 134-137], baleen [138], invertebrates such as the atremate brachiopods [45, 139], Lingula adamsi and Glottidia pyramidata [46], and the protozoa Spirostomum ambiguum [47, 140]. Watabe and Pan [46] commented that the atremate brachiopods could take up Pi from their diet and/or seawater and noted the "extremely high efficiency for phosphate accumulation" since the seawater contained much lower Pi concentrations. Electron microscopic images of brachiopods showed "the ability to maintain large storage of shell mineral components" as unstable "P- and Ca- containing granules" within the cells located in regions of primary and mineralized layers, as well as $\mathrm{Ca}$ - and $\mathrm{P}$-containing precipitates in connective tissues [46]. Watabe and Pan [46] commented that the mechanisms of $\mathrm{Ca}$ and $\mathrm{P}$ accumulation, transport, and precipitation in the tissue were "virtually unknown."

Jones [141] identified ${ }^{45} \mathrm{Ca}$ and ${ }^{32} \mathrm{P}$ uptake into endoplasmic "mineral deposits" in Spirostomum ambiguum and wondered if they might be similar to the $0.1-0.2 \mu \mathrm{m}$ electron-dense granules previously observed in protozoan endoplasm [142]. Jones [141] suggested possible roles of these $\mathrm{Ca}$ - and $\mathrm{P}$-containing granules, including $\mathrm{P}$ storage and an unexplained relationship with mitochondria. $\mathrm{He}$ noted that the granules were similar to dense granules observed in the mitochondria of osteocytes and osteoclasts.

Kashiwa and Komorous [135] demonstrated intra- and extracellular calcium- and P-rich spherules within fresh calcifying cartilage samples from regions preceding endochondral calcification. Kashiwa [143] also identified calcium- and P-rich granules within, and adjacent to, mature and hypertrophic calcifying chondrocytes when staining was performed on fresh samples to avoid the effects of sample preparation on unstable structures. Boonrungsiman et al. [131] observed Ca- and P-rich mitochondrial granules within mineralizing murine osteoblast cultures, and presented evidence of vesicle-mitochondrial interactions with high 
angle-annular dark-field scanning TEM of samples prepared with high-pressure freezing and freeze substitution (HPF-FS) (Fig. 3). Although the presence of these unstable, electrondense, $\mathrm{Ca}$ - and $\mathrm{P}$-containing granules has been identified by different groups, their specific composition is unknown. Fluorescence imaging has shown colocalization of polyPs within murine growth plate calcifying cartilage [31] but not at the resolution required to identify granules. How these granules are secreted into the ECM where they transform into carbonated apatite remains unknown. The realization of these phenomena must lie with the activity of matrix proteins.

\section{Revisiting the Secretory Theory for Biological Apatite Nucleation}

In 1849, Quekett [4] postulated that organisms produce individual mineral precursor "granules," which eventually became the building blocks of bone: "the granules being, in fact, the true ossific matter of the bone." Watt [144] proposed a "secretory theory of mineralization" in 1928, arising from his observations of bone cells secreting granules that appeared to be incorporated into the mineralizing matrix. The theory that apatite mineral precursors were produced within mineralizing cells, processed through the Golgi, and exocytosed to the extracellular space where they are arranged into larger structures was reviewed in 1981 [145]. Weiner and Addadi [146] reviewed the vesicular strategy for four different biomineralization systems, including biological apatite.

\section{Biologically Controlled Apatite Nucleation In Vivo}

Biologically controlled mineralization differs from biologically induced mineralization as it describes mineralization as a consequence of purposeful cell action. This action results in specific mineral sizes and chemistry within the extracellular matrices at specific locations and times [57]. Biologically controlled mineralization may proceed through the
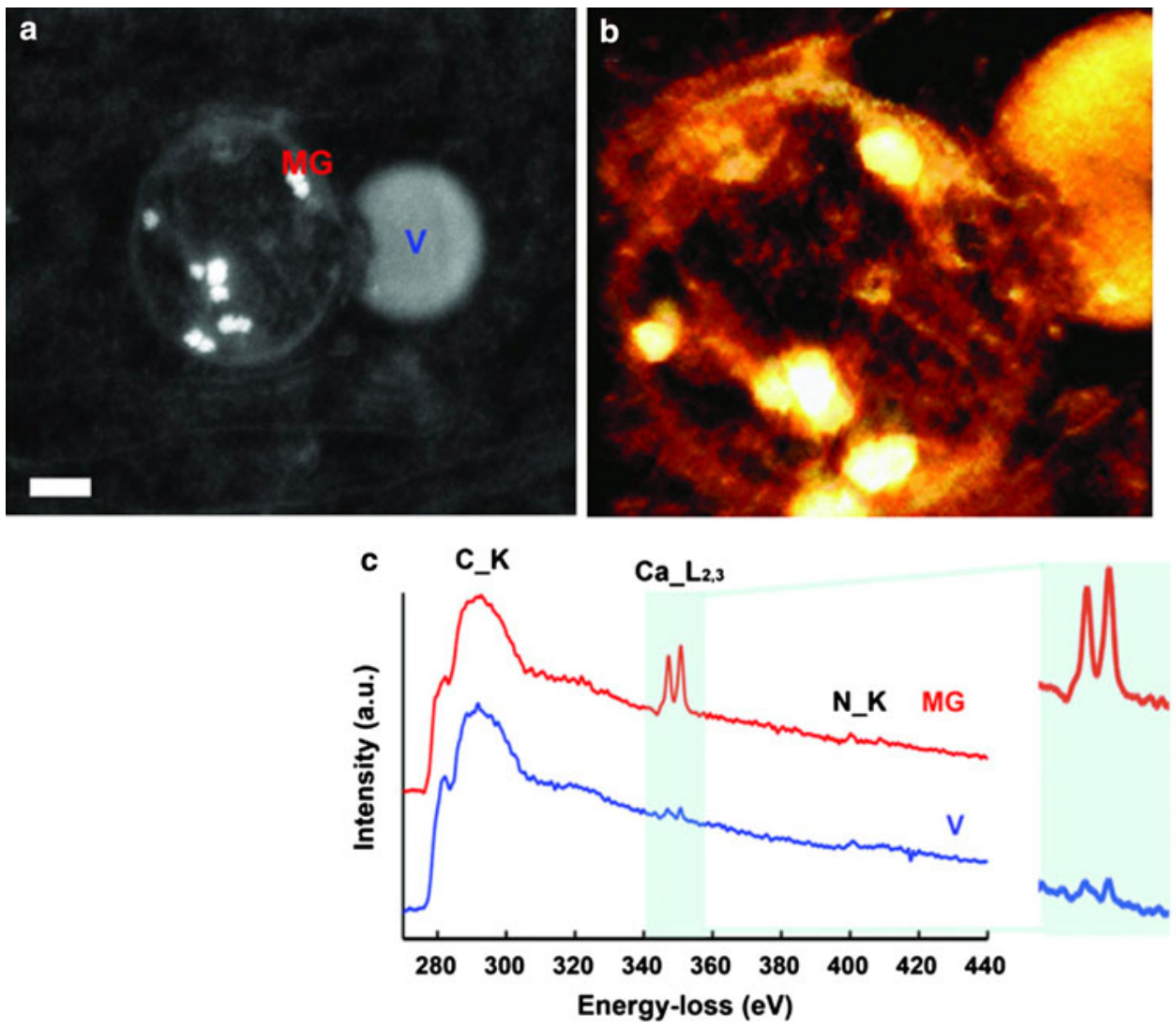

Fig. 3 Analytical electron microscopic evidence of vesicle-mitochondrial interactions in mineralizing osteoblasts. a High-angle annular dark-field scanning TEM image of a dense granule-containing mitochondrion associating with a vesicle within an osteoblast in a mineralized nodule. The sample was prepared by high-pressure freezing and freeze substitution (HPF-FS). (Scale bar $=200 \mathrm{~nm}$ ). b Voltex projection of a 3D tomographic reconstruction showing a mitochondrion conjoined with a vesicle. Dense granules are evident within the mitochondrion. Sample was prepared by HPF-FS. c Electron energy loss spectroscopy (EELS) of specified areas within the mitochondrion and vesicle in a. The mitochondrial granule and vesicle show characteristic calcium L2 and L3 edges at $346 \mathrm{eV}$. All spectra display carbon edges. d Orthoslices at 10-nm intervals through the tomographic reconstruction showing the mitochondrionvesicle interface. The mitochondrial membrane is discontinuous where it conjoins the vesicle (arrows) [131] 


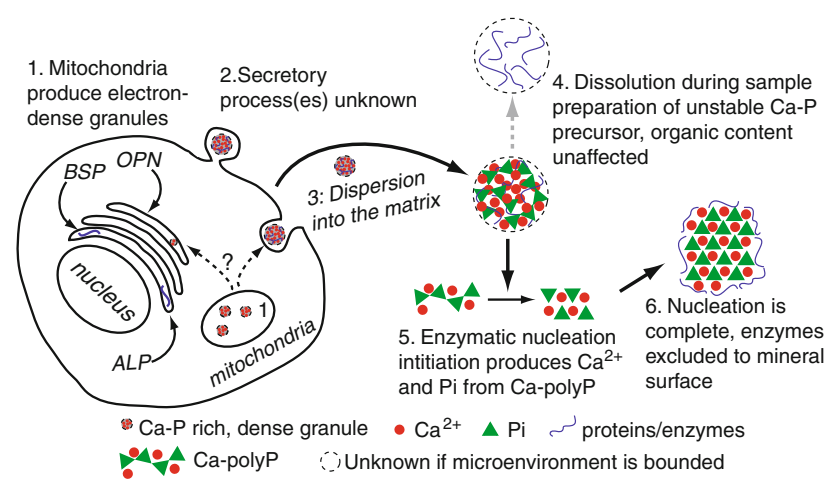

Fig. 4 Proposed controlled apatite biomineralization schematic. (1) Mitochondria produce polyPs from phosphate sources that form complexes with calcium, producing discrete, electron-dense, $\mathrm{Ca}$ - and P-rich granules. (2) Granules may be processed through the transGolgi network (TGN), and then secreted via budding or exocytosis. If processed through the TGN, granules may associate with matrix and/ or noncollagenous proteins as well as phosphatase enzymes. The secreted product is an amorphous $\mathrm{Ca}-\mathrm{P}$-rich granule that contains matrix proteins. It is unknown if the granule is encapsulated. (3) The granule migrates to mineral nucleation sites within the collageneous matrix, where the noncollagenous proteins may play significant roles in granular interaction with the matrix. (4) During sample preparation, these unstable, amorphous granules may be artifactually dissolved so that only the remaining protein component is observed. These may be "crystal ghosts." (5) If a phosphatase enzyme component of the unstable, amorphous precursor is activated within the matrix, the $\mathrm{Ca}-$ polyP component begins to transform into $\mathrm{Ca}^{2+}$ and $\mathrm{Pi}$ components. The local, high concentrations of $\mathrm{Ca}^{2+}$ and Pi nucleate apatite. As the apatite nucleus grows while the polyP depolymerizes, the protein component of the granule is excluded from the growing apatite crystal. This displaces the granule protein components to the surface. (6) The excluded proteins surround the apatite crystal surface, where they control crystal growth and shape, among other functions

production of an intracellular biomineral precursor that is secreted into the ECM. Within the ECM, possibly within a granular microenvironment, matrix-mediated events initiate and control the transformation of the precursor into a mineral. Under biological control, that mineral may have a consistent size, composition, and mineralogy, irrespective of the mineral saturation state in the surrounding ECM. Simultaneous study of both the biochemical and physical chemical processes that initiate apatite biomineralization defies study by many analytical methods.

Bonucci [127] identified initial calcification loci within cartilage that were not associated with collagen, and reviewed the literature on the locus of initial calcification in cartilage and bone. He proposed that collagen fibrils are not the loci of initial calcification in cartilage, that ions may accumulate within mitochondria, and the earliest mineral precursors were found in "roundish bodies of cellular origin" for bone and cartilage. "Osteoblast extrusions" were found in the matrix between collagen fibrils, but their role in bone mineralization was unclear. Kashiwa and Komorous [135] also demonstrated intra- and extracellular calcium and phosphate-rich spherules within fresh calcifying cartilages preceding endochondral calcification. Bonucci reported the direct effect of sample preparation on newly mineralizing tissues, observing that bone crystals are individually surrounded by and integral with an organic phase ("crystal ghosts" [147]). This was observed only if the sample or section was decalcified after embedding [148].

The advantages and limitations of techniques used to examine biomineralization were reviewed by Bonucci [149]. He commented that many of the shortcomings of these techniques stem from the intimate inorganic and organic associations in bone that mask each other unless the sample is decalcified. Unfortunately, many decalcification processes disrupt the matrix [149]. This observation highlights one of the major challenges in studying biologically controlled apatite nucleation. In vivo biological apatite mineralization is controlled by proteins, while at the same time, the crystal nucleation must follow physical chemistry theory. The colocalization of matrix proteins with mineral nucleation may not always infer causation; however, enzyme activity must regulate biologically controlled apatite nucleation. Intracellular packaging of concentrated $\mathrm{Ca}$ and $\mathrm{P}$ stores with regulatory proteins that control apatite mineral nucleation and growth could describe the first step of a controlled biomineralization process. Ennever and Creamer [90] quoted Pautard, who made "an excellent point": "It is unfortunate that the extensive investigation of collagen over the past few years has tended to obstruct serious survey of the nature of other organic substances associated with calcium salts in biological tissues. An almost universal preoccupation with collagen structure and chemistry has obscured the fact that there are . . . bone salts associated with other proteins and with polysaccharides" [150]. Glimcher ([151] citing [152]) summarized two theories of calcification: a "booster" theory, whereby an enzyme or group of enzymes cleaves Pi from an organic substrate, boosting the local Pi concentration, and the theory that the organic matrix induces apatite crystallization. The geology community has identified polyP as the "booster" process substrate in phosphorite formation. Could this Pi-boosting strategy also apply to biologically controlled apatite mineralization, which is ultimately controlled by the action of organic matrix components?

Assuming that matrix proteins are closely associated with $\mathrm{Ca}$-polyP within precursor granules, it is proposed that selective removal of $\mathrm{Ca}$-polyP within the precursor granule would leave behind the organic components, which may describe the "crystal ghosts" (Fig. 4). Enzymatic initiation of apatite nucleation, by polyP depolymerization and increased $\mathrm{Pi}$ and calcium concentrations, would nucleate an ordered $\mathrm{Ca}-\mathrm{Pi}$ structure within the amorphous granule. This nucleation of an ordered mineral would be expected to exclude the granular proteins from the 
nucleating apatite crystal lattice. This is because crystallization processes offer the phenomenon of purifying materials from an impure starting material [153]. As the apatite nucleus grows with more available calcium and $\mathrm{Pi}$, it could exclude the associated granular proteins, eventually displacing them to the apatite mineral surface. When the granular polyP is consumed, the final product could be an apatite crystal now coated by the proteins that were secreted within the granule. This mechanism could provide one explanation for the transport of some proteins to skeletal mineral surfaces.

Minimal matrix disruption is a goal of cryo-electron microscopy (cryo-EM) and cryo sample preparation methods. Cryo-EM and HPF-FS preparation have recently provided evidence of a secretory process for bone mineralization [131, 133, 154, 155]. Mahamid et al. [133] imaged intracellular, membrane-bound, 80-nm-diameter $\mathrm{Ca}-$ and P-rich globules, which in turn are composed of smaller 10-nm spheres in mineralizing embryonic and up to postnatal day 2 murine bones. The nano-spherical subunits were "reminiscent of the intracellular and extracellular ACP nano-spheres dominating the newly-formed bones of the zebrafish fin" (citing $[154,155])$. These nano-spheres were identified within preosteoblasts, osteoblasts, and osteocytes [133]. Electron-dense, extracellular, nano-scale granules within the cryosectioned, mineralizing ECM were not encased by membranes, and exhibited a laminated structure [156]. Mahamid et al. [133] suggested that osteoblasts secrete precursor mineral into extracellular mineralization sites, referring to previous evidence of intracellular mineral exocytosis in osteoblast cell culture [157]. Boonrungsiman et al. [131] also identified Ca- and P-rich granules within mineralizing cell cultures, and proposed a model for bone mineral formation "involving mitochondrial granules, calcium- and phosphorus-containing vesicles, and extracellular mineral precipitation."

If it is assumed that polyP-containing granules are the source of calcium and Pi for apatite nucleation, the granular content could also control the new mineral volume. The size of diatom polyP granules was similar to the size of marine sediment apatite granules, and the polyP was theorized to represent the $\mathrm{Pi}$ content in the apatite granules [80]. Nano-sized bone mineral crystals were observed when isolated by the method of Weiner and Price [158]. Could an analogy be drawn for the formation of these skeletal mineral crystals from the $\mathrm{Ca}$ and $\mathrm{P}$ contents of secreted, nano-sized precursor granules?

\section{Conclusion}

The orchestration of a controlled apatite biomineralization process represents an intricate and still unsolved mystery.
This process requires the biological generation of apatite supersaturation levels to nucleate mineral for both biologically induced and controlled mineralization. Controlled apatite biomineralization processes also require cellular control of apatite nucleation initiation, possibly through the production of intracellular mineral precursors with concentrated calcium and phosphorus stores, and further biological control of matrix-mediated mineral nucleation events.

Challenges in apatite biomineralization continue to be addressed by scientists in the geological, biological, pathological, and medical sciences. Recent advances in geomicrobiology have shown that the biological concentration of Pi from an aqueous environment can be polymerized by mitochondria and stored as polyP. It has been demonstrated that polyP can serve as a concentrated Pi source, resulting in the controlled, extracellular release of Pi by living bacteria. This release into the local environment increases calcium phosphate mineral saturation, leading to biologically induced phosphorite nucleation. It is possible that oral bacteria with polyP stores may induce dental calculus formation with a similar chemical mechanism.

Within marine sediment, the depolymerization of $\mathrm{Ca}-$ polyP granules from diatoms may transform into discrete apatite granules. The identification of calcium- and P-rich granules in the biologically controlled, apatite biomineralizing protozoa, inarticulate brachiopods, and the mineralizing vertebrate skeleton suggest a Ca- and $\mathrm{P}$-concentrating mechanism involving polyP. PolyP has not been identified in these granules, but the low $\mathrm{Ca}: \mathrm{P}$ ratio in vertebrate skeletal amorphous granules suggests its presence. The controlled apatite biomineralization literature contains evidence of the production and secretion of electron-dense, unstable, Ca- and P-containing granules; but their association with apatite nucleation events that are controlled by matrix proteins remains speculative.

It is a paradigm shift in geology that phosphorite-producing organisms use a polyP intermediate to concentrate Pi. Could this paradigm shift apply to controlled apatite biomineralization? It may be useful to integrate the geological perspective of polyP-induced mineralization, the physical-chemical theories of crystal nucleation, and the critical role of organic matrix proteins to understand the complex biological events in calcified tissue formation.

Acknowledgments The German Academic Exchange Service (DAAD) is acknowledged for supporting S.O. with a Faculty Research Visit Grant. This allowed access to the Max Planck Library, which made access to the early literature possible. S.O. thanks Keith Hodson for assistance with the geological terminology, the Helen Riaboff Whiteley Center at the Friday Harbor Laboratories for providing an excellent writing environment, and the Natural Sciences and Engineering Research Council for financial support with their Discovery Grant program. M.A. is supported by the Fonds de la recherche en santé du Québec (FRSQ). The reviewer is thanked for their constructive feedback. 
Open Access This article is distributed under the terms of the Creative Commons Attribution License which permits any use, distribution, and reproduction in any medium, provided the original author(s) and the source are credited.

\section{References}

1. Piccoli PM, Candela PA (2002) Apatite in igneous systems. Rev Mineral Geochem 48:255-292

2. Van Cappellen P, Berner RA (1988) A mathematical model for the early diagenesis of phosphorus and fluorine in marine sediments; apatite precipitation. Am J Sci 288:289-333

3. Thompson DW (1945) On growth and form. MacMillan, New York

4. Quekett J (1849) On the intimate structure of bone, as composing the skeleton, in the four great classes of animals, viz., mammals, birds, reptiles, and fishes, with some remarks on the great value of the knowledge of such structure in determining the affinities of minute fragments of organic remains. J Microsc 2:46-58

5. Crosby CH, Bailey J (2012) The role of microbes in the formation of modern and ancient phosphatic mineral deposits. Front Microbiol 3:e241-e247

6. Fleisch H, Neuman WF (1961) Mechanisms of calcification: role of collagen, polyphosphates, and phosphatase. Am J Physiol 200:1296-1300

7. Francis M (1969) The inhibition of calcium hydroxyapatite crystal growth by polyphosphonates and polyphosphates. Calcif Tissue Res 3:151-162

8. Fleisch H, Straumann F, Schenk R, Bisaz S, Allgower M (1966) Effect of condensed phosphates on calcification of chick embryo femurs in tissue culture. Am J Physiol 211:821-825

9. Kulaev IS, Vagabov VM, Kulakovskaya TV (2005) The biochemistry of inorganic polyphosphates. Wiley, New York

10. Macfarlane MG (1936) Phosphorylation in living yeast. Biochem J 30:1369-1379

11. Schmidt G, Hecht L, Thannheusar SJ (1946) The enzymatic formation and the accumulation of large amounts of a metaphosphate in bakers' yeast under certain conditions. J Biol Chem 166:775-776

12. Wiame JM (1947) Étude d'une substance polyphosphorée, basophile, et métachromique chez les levures. Biochim Biophys Acta 1:234-255

13. Wiame JM (1949) The occurrence and physiological behaviour of two metaphosphate fractions in yeast. J Biol Chem 178:919-929

14. Salhany JM, Yamane T, Shulman RG, Ogawa S (1975) High resolution ${ }^{31} \mathrm{P}$ nuclear magnetic resonance studies of intact yeast cells. Proc Natl Acad Sci USA 72:4966-4970

15. Allan RA, Miller JJ (1980) Influence of $S$-adenosylmethionine on DAPI-induced fluorescence of polyphosphate in the yeast vacuole. Can J Microbiol 26:912-920

16. Hupfer M, Glöss S, Schmieder P, Grossart H-P (2008) Methods for detection and quantification of polyphosphate and polyphosphate accumulating microorganisms in aquatic sediments. Int Rev Hydrobiol 93:1-30

17. Kapuscinski J (1995) DAPI: a DNA-specific fluorescent probe. Biotech Histochem 70:220-233

18. Van Wazer JR, Campanella DA (1950) Structure and properties of the condensed phosphates. IV. Complex ion formation in polyphosphate solutions. J Am Chem Soc 72:655-663

19. Omelon S, Grynpas M (2011) Polyphosphates affect biological apatite nucleation. Cells Tissues Organs 194:171-175

20. Pavlov E, Aschar-Sobbi R, Campanella M, Turner RJ, Gómez-García MR, Abramov AY (2010) Inorganic polyphosphate and energy metabolism in mammalian cells. J Biol Chem 285:9420-9428
21. Kulakovskaya T, Lichko L, Vagabov V, Kulaev I (2010) Inorganic polyphosphates in mitochondria. Biochemistry (Moscow) $75: 825-831$

22. Kulakovskaya T (2012) Inorganic polyphosphates: jack of all trades. Biochem Physiol 1:e107

23. Greenawalt JW, Rossi CS, Lehninger AL (1964) Effect of active accumulation of calcium and phosphate ions on the structure of rat liver mitochondria. J Cell Biol 23:21-38

24. Lehninger AL, Rossi CS, Greenawalt JW (1963) Respirationdependent accumulation of inorganic phosphate and $\mathrm{Ca}$ ions by rat liver mitochondria. Biochem Biophys Res Commun 10:444-448

25. Lehninger AL (1970) Mitochondria and calcium ion transport. Biochem J 119:129-138

26. Raven JA, Knoll AH (2010) Non-skeletal biomineralization by eukaryotes: matters of moment and gravity. Geomicrobiol $\mathbf{J}$ 27:572-584

27. Omelon S, Baer A, Coyle T, Pilliar RM, Kandel R, Grynpas M (2008) Polymeric crystallization and condensation of calcium polyphosphate glass. Mater Res Bull 43:68-80

28. Docampo R, de Souza W, Miranda K, Rohloff P, Moreno SNJ (2005) Acidocalcisomes-conserved from bacteria to man. Nat Rev Microbiol 3:251-261

29. de Jager H-J, Heyns AM (1998) Kinetics of acid-catalyzed hydrolysis of a polyphosphate in water. J Phys Chem A 102:2838-2841

30. Millán JL (2006) Mammalian alkaline phosphatases: from biology to applications in medicine and biotechnology. Wiley, New York

31. Omelon S, Georgiou J, Henneman ZJ, Wise LM, Sukhu B, Hunt T, Wynnyckyj C, Holmyard D, Bielecki R, Grynpas MD (2009) Control of vertebrate skeletal mineralization by polyphosphates. PLoS ONE 4:e5634

32. Smith SA, Mutch NJ, Baskar D, Rohloff P, Docampo R, Morrissey JH (2006) Polyphosphate modulates blood coagulation and fibrinolysis. Proc Natl Acad Sci USA 103:903-908

33. Fortuna R, Anderson HC, Carty R, Sajdera S (1980) Enzymatic characterization of the matrix vesicle alkaline phosphatase isolated from bovine fetal epiphyseal cartilage. Calcif Tissue Int 30:217-225

34. Dyhrman ST, Jenkins BD, Rynearson TA, Saito MA, Mercier ML, Alexander H, Whitney LP, Drzewianowski A, Bulygin VV, Bertrand EM, Wu Z, Benitez-Nelson C, Heithoff A (2012) The transcriptome and proteome of the diatom Thalassiosira pseudonana reveal a diverse phosphorus stress response. PLoS ONE 7:e33768

35. Pan Y, Fleet ME (2002) Compositions of the apatite-group minerals: substitution mechanisms and controlling factors. Rev Mineral Geochem 48:13-49

36. McConnell D (1973) Apatite: its crystal chemistry, mineralogy, utilization, and geologic and biologic occurrences. Springer, New York

37. Hewitt RA (1980) Microstructural contrasts between some sedimentary francolites. J Geol Soc Lond 137:661-667

38. Nathan Y (1984) The mineralogy and geochemistry of phosphorites. In: Nriagu JO, Moore PB (eds) Phosphate minerals. Springer, Berlin, pp 275-291

39. Baturin GN, Bezrukov PL (1979) Phosphorites on the sea floor and their origin. Mar Geol 31:317-332

40. McConnell D (1950) The petrography of rock phosphates. J Geol 58:16-23

41. Filippelli GM (2011) Phosphate rock formation and marine phosphorus geochemistry: the deep time perspective. Chemosphere 84:759-766

42. Bailey JV, Corsetti FA, Greene SE, Crosby CH, Liu P, Orphan VJ (2013) Filamentous sulfur bacteria preserved in modern and 
ancient phosphatic sediments: implications for the role of oxygen and bacteria in phosphogenesis. Geobiology 11:397-405

43. McConnell D (1965) Precipitation of phosphates in sea water. Econ Geol 60:1059-1062

44. von Klement R (1938) Die anorganische Skelettsubstanz, ihre Zusammensetzung, natürlich und künstliche Bildung. Naturwissenschaften 1938:145-152

45. McConnell D (1963) Inorganic constituents in the shell of the living brachiopod Lingula. Geol Soc Am Bull 74:363-364

46. Watabe N, Pan C-M (1984) Phosphatic shell formation in atremate brachiopods. Am Zool 24:977-985

47. Pautard FGE (1959) Hydroxyapatite as a developmental feature of Spirostomum ambiguum. Biochim Biophys Acta 35:33-46

48. Levy M (1894) Chemische Untersuchungen über osteomalacische Knochen. Z Phys Chem 19:239-270

49. de Jong WF (1926) La substance minérale dans les os. Recl Trav Chim Pays Bas 45:445-448

50. Taylor NW, Sheard C (1929) Microscopic and X-ray investigations on the calcification of tissue. J Biol Chem 81:479-493

51. McConnell D (1952) The crystal chemistry of carbonate apatites and their relationship to the composition of calcified tissues. J Dent Res 31:53-63

52. Weiner S, Wagner HD (1998) The material bone: structuremechanical function relations. Annu Rev Mater Res 28:271-298

53. Tadic D, Peters F, Epple M (2002) Continuous synthesis of amorphous carbonated apatites. Biomaterials 23:2553-2559

54. LeGeros RZ (1991) Calcium phosphates in oral biology and medicine. Monogr Oral Sci 15:1

55. Elliott JC (1994) Structure and chemistry of the apatites and other calcium orthophosphates. Elsevier, Amsterdam

56. McConnell D (1965) Crystal chemistry of hydroxyapatite: its relation to bone mineral. Arch Oral Biol 10:421-431

57. Lowenstam HA, Weiner S (1989) On biomineralization. Oxford University Press, New York

58. Eppell SJ, Tong W, Katz JL, Kuhn L, Glimcher MJ (2001) Shape and size of isolated bone mineralites measured using atomic force microscopy. J Orthop Res 19:1027-1034

59. Bonar LC, Roufosse AH, Sabine WK, Grynpas MD, Glimcher MJ (1983) X-ray diffraction studies of the crystallinity of bone mineral in newly synthesized and density fractionated bone. Calcif Tissue Int 35:202-209

60. Rey C, Combes C, Drouet C, Glimcher MJ (2009) Bone mineral: update on chemical composition and structure. Osteoporos Int 20:1013-1021

61. Pasteris JD, Wopenka B, Freeman JJ, Rogers K, Valsami-Jones E, van der Houwen JAM, Silva MJ (2004) Lack of OH in nanocrystalline apatite as a function of degree of atomic order: implications for bone and biomaterials. Biomaterials 25:229-238

62. Neuman WF, Neuman MW (1958) The chemical dynamics of bone mineral. Univesity of Chicago Press, Chicago

63. Morse JW (1974) Dissolution kinetics of calcium carbonate in sea water, III. A new method for the study of carbonate reaction kinetics. Am J Sci 274:97-107

64. Kashchiev D, van Rosmalen GM (2003) Nucleation in solutions revisited. Cryst Res Technol 38:555-574

65. Larsen MJ (1986) An investigation of the theoretical background for the stability of the calcium-phosphate salts and their mutual conversion in aqueous solutions. Arch Oral Biol 31:757-761

66. Glimcher MJ, Hodge AJ, Schmitt FO (1957) Macromolecular aggregation states in relation to mineralization: the collagenhydroxyapatite system as studied in vitro. Proc Natl Acad Sci USA 43:860

67. Strates B, Neuman WF (1958) On the mechanisms of calcification. Proc Soc Exp Biol Med 97:688-691
68. Kratz A, Ferraro M, Sluss PM, Lewandrowski KB (2004) Laboratory reference values. N Engl J Med 351:1548-1564

69. Sandin K, Kloo L, Nevsten P, Wallenberg RL, Olsson LF (2009) Formation of carbonated apatite particles from a supersaturated inorganic blood serum model. J Mater Sci Mater Med 20: $1677-1687$

70. Robison R (1923) The possible significance of hexosephosphoric esters in ossification. Biochem J 17:286-293

71. Martland M, Robison R (1924) The possible significance of hexosephosphoric esters in ossification: part V. The enzyme in the early stages of bone development. Biochem J 18:1354

72. Kazakov A (1937) The phosphorite facies and the genesis of phosphorites. Geological Investigations of Agricultural Ores; USSR Trans. Sci Inst Fert Insectofung 142:93-113

73. Blackwelder E (1916) The geologic role of phosphorus. Proc Natl Acad Sci USA 2:490-495

74. Lacroix A (1910) Minéralogie de la France et de ses colonies. Librairie Polytechnique Baudry et Cie, Paris

75. de Montigny C, Prairie YT (1993) The relative importance of biological and chemical processes in the release of phosphorus from a highly organic sediment. Hydrobiologia 253:141-150

76. Einsele W (1938) Über chemische und kolloidchemische Vorgänge in Eisen-Phosphat-Systemen unter limnochemischen und limnogeologischen Gesichtspunkten. Arch Hydrobiol 33:361-387

77. Mortimer CH (1942) The exchange of dissolved substances between mud and water in lakes. J Ecol 30:147-201

78. Levin GV, Shapiro J (1965) Metabolic uptake of phosphorus by wastewater organisms. Water Environ Res 37:800-821

79. Schulz HN, Schulz HD (2005) Large sulfur bacteria and the formation of phosphorite. Science 307:416-418

80. Diaz J, Ingall E, Benitez-Nelson C, Paterson D, de Jonge MD, McNulty I, Brandes JA (2008) Marine polyphosphate: a key player in geologic phosphorus sequestration. Science 320:652-655

81. Lowenstam HA (1981) Minerals formed by organisms. Science 211:1126-1131

82. Cayeux L (1936) Existence of many bacteria in sedimentary phosphates of all ages-consequences. C R Hebd Seances Acad Sci 203:1198-1200

83. Nathan Y, Bremner JM, Loewenthal RE, Monteiro P (1993) Role of bacteria in phosphorite genesis. Geomicrobiol $\mathrm{J}$ 11:69-76

84. Marais GvR, Loewenthal R, Siebritz I (1983) Observations supporting phosphate removal by biological excess uptake: a review. Water Sci Technol 15:15-41

85. Brüchert V, Jørgensen BB, Neumann K, Riechmann D, Schlösser M, Schulz H (2003) Regulation of bacterial sulfate reduction and hydrogen sulfide fluxes in the central Namibian coastal upwelling zone. Geochim Cosmochim Acta 67: $4505-4518$

86. Goldhammer T, Bruchert V, Ferdelman TG, Zabel M (2010) Microbial sequestration of phosphorus in anoxic upwelling sediments. Nat Geosci 3:557-561

87. Schulz HN, Brinkhoff T, Ferdelman TG, Mariné MH, Teske A, Jørgensen BB (1999) Dense populations of a giant sulfur bacterium in Namibian shelf sediments. Science 284:493-495

88. Conkright ME, Gregg WW, Levitus S (2000) Seasonal cycle of phosphate in the open ocean. Deep Sea Res Part 1 Oceanogr Res Pap 47:159-175

89. Brock J, Schulz-Vogt HN (2011) Sulfide induces phosphate release from polyphosphate in cultures of a marine Beggiatoa strain. ISME J 5:497-506

90. Ennever J, Creamer H (1967) Microbiologic calcification: bone mineral and bacteria. Calcif Tissue Res 1:87-93

91. Bulleid A (1925) An experimental study of Leptothrix buccalis. Br Dent J 46:289-300 
92. Jensen AT, Danø M (1954) Crystallography of dental calculus and the precipitation of certain calcium phosphates. J Dent Res 33:741-750

93. Grøn P, van Campen GJ, Lindstrom I (1967) Human dental calculus: inorganic chemical and crystallographic composition. Arch Oral Biol 12:829-837

94. Zapanta Le Geros R (1974) Variations in the crystalline components of human dental calculus: i. crystallographic and spectroscopic methods of analysis. J Dent Res 53:45-50

95. Sundberg M, Friskopp J (1985) Crystallography of supragingival and subgingival human dental calculus. Eur J Oral Sci 93:30-38

96. Poff AM, Pearce EIF, Larsen MJ, Cutress TW (1997) Human supragingival in vivo calculus formation in relation to saturation of saliva with respect to calcium phosphates. Arch Oral Biol 42:93-99

97. Fleisch H, Bisaz S (1962) Isolation from urine of pyrophosphate, a calcification inhibitor. Am J Physiol 203:671-675

98. Rohanizadeh R, LeGeros RZ (2005) Ultrastructural study of calculus-enamel and calculus-root interfaces. Arch Oral Biol 50:89-96

99. Ennever J (1960) Intracellular calcification by oral filamentous microorganisms. J Periodont 31:304-307

100. Ennever J, Vogel JJ, Streckfuss JL (1971) Synthetic medium for calcification of Bacterionema matruchotii. J Dent Res 50:1327-1330

101. Lai CH, Listgarten MA (1980) Comparative ultrastructure of certain Actinomyces species, Arachnia, Bacterionema and Rothia. J Periodontol 51:136-154

102. Takazoe I, Nakamura T (1965) The relation between metachromatic granules and intracelluar calcificaiton of Bacterionema matruchotti. Bull Tokyo Dent Coll 35:29-42

103. Liu H, Segreto VA, Baker RA, Vastola KA, Ramsey LL, Gerlach RW (2002) Anticalculus efficacy and safety of a novel whitening dentifrice containing sodium hexametaphosphate: a controlled six-month clinical trial. J Clin Dent 13:25-28

104. Briner WW, Francis MD (1973) In vitro and in vivo evaluation of anti-calculus agents. Calcif Tissue Res 11:10-22

105. Tanzer J, Hageage G Jr (1970) Polyphosphate inhibition of growth of plaques formed by streptococci and diphtheroids implicated in oral disease. Infect Immun 1:604

106. Franker CK, McGee MP, Rezzo TP (1979) Alkaline phosphatase activity in a strain of Bacterionema matruchotii. J Dent Res 58:1705-1708

107. Lo Storto S, Silvestrini G, Bonucci E (1992) Ultrastructural localization of alkaline and acid phosphatase activities in dental plaque. J Periodont Res 27:161-166

108. Cayeux L (1936) Reticulated structure of silica, observed in the Precambrian phtanites and Suessonian phosphates. C R Hebd Seances Acad Sci 203:6-8

109. Kuenzler EJ, Ketchum BH (1962) Rate of phosphorus uptake by Phaeodactylum tricornutum. Biol Bull 123:134-145

110. Fisher KA (1971) Polyphosphate in a chlorococcalean alga. Phycologia 10:177-182

111. Crawford RM (1973) The protoplasmic ultrastructure of the vegetative cell of Melosira varians C. A. Agardh1. J Phycol 9:50-61

112. Harold FM (1966) Inorganic polyphosphates in biology: structure, metabolism, and function. Bacteriol Rev 30:772-794

113. Siderius M, Musgrave A, van den Ende H, Koerten H, Cambier P, van der Meer P (1996) Chlamydomonas eugametos (Chlorophyta) stores phosphate in polyphosphate bodies together with calcium. J Phycol 32:402-409

114. Ruttenberg KC, Dyhrman ST (2005) Temporal and spatial variability of dissolved organic and inorganic phosphorus, and metrics of phosphorus bioavailability in an upwelling-dominated coastal system. J Geophys Res Oceans 110:C10S13

115. Shapiro I, Greenspan J (1969) Are mitochondria directly involved in biological mineralisation? Calcif Tissue Res 3:100-102

116. Gonzales F, Karnovsky MJ (1961) Electron microscopy of osteoblasts in healing fractures of rat bone. J Biophys Biochem Cytol 9:299-316

117. Sutfin LV, Holtrop ME, Ogilvie RE (1971) Microanalysis of individual mitochondrial granules with diameters less than 1000 angstroms. Science 174:947-949

118. Martin JH, Matthews JL (1969) Mitochondrial granules in chondrocytes. Calcif Tissue Res 3:184-193

119. Landis WJ, Paine MC, Glimcher MJ (1980) Use of acrolein vapors for the anhydrous preparation of bone tissue for electron microscopy. J Ultrastruct Res 70:171-180

120. Matthews JL (1970) Ultrastructure of calcifying tissues. Am J Anat 129:450-457

121. Martin JHPD, Matthews JLPD (1970) Mitochondrial granules in chondrocytes, osteoblasts and osteocytes: an ultrastructural and microincineration study. Clin Orthop Relat Res 68:273-278

122. Matthews JL, Martin JH, Sampson HW, Kunin AS, Roan JH (1970) Mitochondrial granules in the normal and rachitic rat epiphysis. Calcif Tissue Res 5:91-99

123. Landis WJ, Glimcher MJ (1982) Electron optical and analytical observations of rat growth plate cartilage prepared by ultracryomicrotomy: the failure to detect a mineral phase in matrix vesicles and the identification of heterodispersed particles as the initial solid phase of calcium phosphate deposited in the extracellular matrix. J Ultrastruct Res 78:227-268

124. Gay C, Schraer H (1975) Frozen thin-sections of rapidly forming bone: bone cell ultrastructure. Calcif Tissue Res 19:39-49

125. Landis WJ, Glimcher MJ (1978) Electron diffraction and electron probe microanalysis of the mineral phase of bone tissue prepared by anhydrous techniques. J Ultrastruct Res 63:188-223

126. Landis WJ, Hauschka BT, Rogerson CA, Glimcher MJ (1977) Electron microscopic observations of bone tissue prepared by ultracryomicrotomy. J Ultrastruct Res 59:185-206

127. Bonucci E (1971) The locus of initial calcification in cartilage and bone. Clin Orthop Relat Res 78:108-139

128. Bonucci E, Derenzini M, Marinozzi V (1973) The organicinorganic relationship in calcified mitochondria. J Cell Biol 59:185-211

129. Thomas RS, Greenawalt JW (1968) Microincineration, electron microscopy, and electron diffraction of calcium phosphate-loaded mitochondria. J Cell Biol 39:55-76

130. Weinbach EC, von Brand T (1967) Formation, isolation and composition of dense granules from mitochondria. Biochim Biophys Acta 148:256-266

131. Boonrungsiman S, Gentleman E, Carzaniga R, Evans ND, McComb DW, Porter AE, Stevens MM (2012) The role of intracellular calcium phosphate in osteoblast-mediated bone apatite formation. Proc Natl Acad Sci USA 109:14170-14175

132. Christoffersen J, Christoffersen MR, Kibalczyc W, Andersen FA (1989) A contribution to the understanding of the formation of calcium phosphates. J Cryst Growth 94:767-777

133. Mahamid J, Sharir A, Gur D, Zelzer E, Addadi L, Weiner S (2011) Bone mineralization proceeds through intracellular calcium phosphate loaded vesicles: a cryo-electron microscopy study. J Struct Biol 174:527-535

134. Maximow AA (1910) Untersuchungen über Blut und Bindegewebe III Die embryonale Histogenese des Knochenmarks der Säugetiere. Arch Mikr Anat bd 76 (1910-1911)

135. Kashiwa HK, Komorous J (1971) Mineralized spherules in the cells and matrix of calcifying cartilage from developing bone. Anat Rec 170:119-127 
136. Ali SY, Sajdera SW, Anderson HC (1970) Isolation and characterization of calcifying matrix vesicles from epiphyseal cartilage. Proc Natl Acad Sci USA 67:1513-1520

137. Lester KS, Ash MM Jr (1980) Scanning electron microscopy of mineralized cartilage in rat mandibular condyle. J Ultrastruct Res 72:141-150

138. Pautard FGE (1970) The mineral phase of calcified cartilage, bone and baleen. Calcif Tissue Res 4:34-36

139. LeGeros R, Pan C-M, Suga S, Watabe N (1985) Crystallochemical properties of apatite in atremate brachiopod shells. Calcif Tissue Int 37:98-100

140. Finley HE, Brown CA, Daniel WA (1964) Electron microscopy of the ectoplasm and infraciliature of Spirostomum ambiguum. J Eukaryot Microbiol 11:264-280

141. Jones AR (1967) Calcium and phosphorus accumulation in Spirostomum ambiguum. J Eukaryot Microbiol 14:220-225

142. Daniel WA, Mattern CFT (1965) Some observations on the structure of the peristomial membranelle of Spirostomum ambiguum. J Eukaryot Microbiol 12:14-27

143. Kashiwa H (1970) Mineralized spherules in cartilage of bone revealed by cytochemical methods. Am J Anat 129:459-465

144. Watt J (1928) The development of bone: (a) the process of development in bones of different types; (b) normal physiologic calcification of the matrix in cartilage and in bone; (c) the problem of the manner of deposition of the calcium salts. Arch Surg 17:1017-1046

145. Pautard F (1981) Calcium phosphate microspheres in biology. Prog Cryst Growth Charact Mater 4:89-98

146. Weiner S, Addadi L (2011) Crystallization pathways in biomineralization. Annu Rev Mater Res 41:21-40

147. Bonucci E (2002) Crystal ghosts and biological mineralization: fancy spectres in an old castle, or neglected structures worthy of belief? J Bone Miner Metab 20:249-265
148. Bonucci E, Reurink J (1978) The fine structure of decalcified cartilage and bone: a comparison between decalcification procedures performed before and after embedding. Calcif Tissue Res 25:179-190

149. Bonucci E (2005) Calcified tissue histochemistry: from microstructures to nanoparticles. Eur J Histochem 49:1-10

150. Pautard F (1966) A biomolecular survey of calcification. In: Fleisch H, Blackwood JJ, Owen M (eds) Proceedings of the Third European Symposium on Calcified Tissues. Springer, New York, p 108-122

151. Glimcher MJ (1959) Molecular biology of mineralized tissues with particular reference to bone. Rev Mod Phys 31:359-393

152. Freudenberg E, György P (1921) Über Kalkbildung durch tierische Gewebe. III. Biochem Z 118:50-54

153. Myerson A (2002) Handbook of industrial crystallization. Butterworth-Heinemann, Boston

154. Mahamid J, Sharir A, Addadi L, Weiner S (2008) Amorphous calcium phosphate is a major component of the forming fin bones of zebrafish: indications for an amorphous precursor phase. Proc Natl Acad Sci USA 105:12748-12753

155. Mahamid J, Aichmayer B, Shimoni E, Ziblat R, Li C, Siegel S, Paris O, Fratzl P, Weiner S, Addadi L (2010) Mapping amorphous calcium phosphate transformation into crystalline mineral from the cell to the bone in zebrafish fin rays. Proc Natl Acad Sci USA 107:6316-6321

156. Mahamid J, Addadi L, Weiner S (2011) Crystallization pathways in bone. Cells Tissues Organs 194:92-97

157. Rohde M, Mayer H (2007) Exocytotic process as a novel model for mineralization by osteoblasts in vitro and in vivo determined by electron microscopic analysis. Calcif Tissue Int 80:323-336

158. Weiner S, Price P (1986) Disaggregation of bone into crystals. Calcif Tissue Int 39:365-375 